ISSN 0258-7122

Bangladesh J. Agril. Res. 36(3) : 455-468, September 2011

\title{
GROWTH AND YIELD COMPONENTS OF WHEAT UNDER WATER STRESS OF DIFFERENT GROWTH STAGES
}

\begin{abstract}
M. AKRAM ${ }^{1}$
Abstract

A field experiment was conducted to determine the sensitivity of wheat to water stress and changes in water relations and yield of wheat (Triticum aestivum L.) under water stress conditions applied at different growth stages. The experiment comprised of two wheat cultivars and four water stress treatments, maintained by withholding water at tillering, anthesis, and at both stages. Water stress caused reduction in leaf relative water contents, water potential, osmotic potential, turgor potential, growth and yield components of both the wheat cultivars. The results indicated that high value of relative water contents were associated with increased yield and yield components. Consecutive stresses at both growth stages caused severe reduction in yield and yield components in both cultivars of wheat.
\end{abstract}

Keywords: Water stress, water relations, growth, Triticum aestivum, yield components.

\section{Introduction}

Wheat is the major cereal crop of rabi season and is grown in almost every part of Pakistan. It is cultivated under rainfed conditions and the area near the tail end of canals where shortage of water is often experienced. The average yield of wheat is quite low in such areas, which is mainly due to shortage of water (Ashraf, 1998). Water stress not only a ffects the morphology but also severely affects the metabolism of the plant. The extent of modification depends upon the cultivar, growth stage, duration and intensity of stress (Mark and Antony. 2005; Araus et al., 2002).

Water stress at anthesis reduces pollination and thus less number of grains are formed per spike which results in the reduction of grain yield (Ashraf, 1998). Adequate water at or after anthesis period not only allows the plant to increase photosynthesis rate but also gives extra time to translocate the carbohydrate to grains (Zhang and Oweis, 1998) which improves grain size and thereby lead to increase grain yield. Decrease in growth rate is caused by reduction in radiation use efficiency when drought was imposed at various growth stages, such as tillering, booting, earing, anthesis, and grain development stages (Ashraf., 1998b). Better performance of crop depends upon availability of water during these stages (Ashraf et al., 1994; Sarwar, 1994; Jamal et al., 1996).

${ }^{1}$ Pulses Research Institute, AARI, Faisalabad, Pakistan. 
The crop water need is related to moisture sensitive periods. Salter and Goude (1967) delined such periods as "certain development phases in which the plant is, or appeared by its observed response, to be more sensitive to moisture conditions than at other stages of development”. If moisture sensitive periods could be identified for wheat crop under field conditions, it would have an important implication for irrigation practices.

All stages of crop growth are not uniformly susceptible to water scarcity. On the other hand, some stages can cope-up with water shortage very well, while others are more susceptible and water shortages at such stages may result in distinct yield losses. Moisture stress is known to reduce biomass, tillering ability, grains per spike and grain size at any stage when it occurs. So, the overall effect of moisture stress depends on intensity and length of stress (Bukhat, 2005). Water stress imposed during later stages might additionally cause a reduction in number of kernels/ear and kernel weight (Gupta et. al., 2001; Dencic et al., 2000).

Efficient and purposeful utilization of water is, therefore, important under water shortage cnditions. Different responses of wheat genotypes to moisture stress are well documented (Ashraf et al., 1094: I 998). Hence there is a need for selection of such wheat varieties which could mature and produce better yield with limited supply of water. The present attempt was made to find out a drought tolerant variety of wheat for drought prone area of Pakistan. In the view of above consideration, the present study was conducted to determine the optimum water requirement for wheat crop, identification of sensitive growth stages in wheat to water deficit conditions and to estimate the effect of drought on water relation and yield of wheat crop under climatic conditions of Faisalahad, Pakistan.

\section{Materials and Method}

Field study was conducted to assess the effect of water stress applied at different growth stages on growth, yield, and water relation of wheat. Very little rainfall, low humidity, and bright sunny days were the characteristic features of the growing season. The experiment was carried out at research area of Department of Crop Physiology, University of Agriculture, Faisalabad, Pakistan during the year 2005. It comprised of two wheat cultivars i.e., Inqlab-9l and Uqab-2000 and four water stress treatments i.e., $\mathrm{T}_{0}$ control (No water stress imposed and plots were never allowed to dry out), $T_{1}$ (Water stress was imposed at stem elongation stage, $T_{2}$ (Water stress imposed at anthesis stage), $T_{3}$ (Water stress imposed at stem elongation and anthesis stage). The experiment was laid out in a randomized complete block design (RCBD) in a factorial arrangement with three replications. Weather data during the whole course of study in both the years are given in Table 1. To overcome the problem of rainfall, the stressed plots were covered with polythene sheet by the help of iron stands. Water stress was 
imposed by withholding irrigation at stress periods. Control plots were inigated as frequently as required. The crop was sown at the rate of $125 \mathrm{~kg}$ seed/ha with the help of single row hand drill in $25 \mathrm{~cm}$ apart from row to row. The plots were fertilized at the rate of 150,100 and $140 \mathrm{~kg} \mathrm{~N} \mathrm{P}_{2} \mathrm{O}_{5}$ and $\mathrm{K}_{2} \mathrm{O}$ ha ${ }^{-1}$, respectively as urea, DAP and SOP. All agnornic practices were carried out uniformly for all treatments.

Table 1. Weather data during the course of study.

\begin{tabular}{l|l|l|l}
\hline \multicolumn{1}{c|}{ Months } & \multicolumn{1}{c|}{$\begin{array}{c}\text { Mean monthly } \\
\text { temperatutre }\left({ }^{\circ} \mathrm{C}\right)\end{array}$} & $\begin{array}{c}\text { Mean monthly } \\
\text { relative humidity (\%) }\end{array}$ & $\begin{array}{c}\text { Total monthly } \\
\text { rainfall }(\mathrm{mm})\end{array}$ \\
\hline November & 20.30 & 47.0 & 0.00 \\
December & 13.9 & 50.5 & 2.00 \\
January & 10.40 & 41.5 & 0.00 \\
February & 13.1 & 40.3 & 3.00 \\
March & 22.7 & 37.8 & 0.00 \\
April & 31.5 & 16.0 & 5.50 \\
May & 30.80 & 30.2 & 16.00 \\
\hline
\end{tabular}

Relative water contents (RWC) were measured by using flag leaf after imposing the water stress. Instantaneously after cutting at the base of lamina, leaves were preserved within plastic bags and in time transferred to the laboratory. Fresh weight was determined just after removal. Turgid weight was measured after saturating leaves in distilled water for 24 hours at room temperature. After, saturating leaves were quickly and carefully blotted dry with tissue paper and then turgid weight was taken. Dry weight was measured after oven drying the leaves samples at $72^{\circ} \mathrm{C}$. RWC was calculated by using the following formula (Karrou and Maranville, 995).

RWC (\%) $=\frac{\text { Fresh weight }- \text { Dry weight }}{\text { Turgid weight }- \text { Dry weight }} \times 100$

Leaf water potential of flag leaf $\left(\psi_{\mathrm{w}}\right)$ was determined only once i.e., seven days after imposing water stress at anthesis stage. A single flag leaf was placed in the pressure chamber (ELE International, Israel) with the cut surface protruding out of the hole. Pressure was applied to the leaf from a cylinder of compressed gas until xylem sap appeared at the cut surface. This balancing pressure was regarded as the tension originally existing in the xylem sap and approximately equal to water potential of the cells. Sampling was done between 6.00 and 9.00 a.m. to avoid evaporation losses.

The same leaf, mentioned above, was frozen in a freezer below $-20^{\circ} \mathrm{C}$ for more than seven days, then frozen leaf materials was thawed and cell sap was 
extracted by pressing the material with the help of glass rod. A drop of sap was used directly for the determination of osmotic potential $\left(\psi_{\mathrm{p}}\right)$ in a vapor pressure Osmometer (Osmette VAPRO-5520, USA) calibrated in m osmol/kg.

The turgor potential was calculated as the difference between water potential $\left(\psi_{\mathrm{w}}\right)$ and osmotic pential $\left(\psi_{\mathrm{s}}\right)$ values $\psi_{\mathrm{p}}=\psi_{\mathrm{w}}-\psi_{\mathrm{s}}$.

Leaf area index (LAI) was calculated as the ratio of leaf area to land area

LAT $=\frac{\text { Leaf area }}{\text { Land area }}$

Crop growth rate (CGR) was calculated as proposed by Hunt (1978).

$\mathrm{CGR}=\frac{\mathrm{W}_{2}-\mathrm{W}_{1}}{\mathrm{t}_{2}-\mathrm{t}_{1}}$

$\mathrm{W}_{1}$ : first dry weight and $\mathrm{W}_{2}$ : second dry weight and t: first sampling for dry eight and $t_{2}$ : second sampling for dry weight and time interval between first and second sampling was fifteen days.

Net assimilation rate (NAR) was calculated by using the formula of Hunt (1978).

$\mathrm{NAR}=\frac{\mathrm{TDM}}{\mathrm{LAD}}$

TDM and LAD is the total dry matter and leaf area duration, respectively.

Harvest index (HI) was determined by using the following as

$\mathrm{HI}=\frac{\text { Grain yield }}{\text { Biological yield }} \times 100$

At maturity, the plants from each treatment were harvested and yield and yield components were recorded.

\section{Statistical analysis}

Data collected during the course of this study were statistically analyzed using Fishers analysis of variance technique and significant means were separated using least significant difference test (LSD) at 5\% probability level (Steel et al., 1997).

\section{Results}

\section{Water potentials}

Relative water content was reduced by water stress applied at different growth stages (Fig. IA) to both the wheat cultivars. The highest RWC was recorded in 
the plant grown with normal irrigations $\left(T_{0}\right)$ and the minimum was in $T_{3}$. Wheat cultivar lnqlab-91 maintained significantly greater RWC than Uqab-2000. The data pertaining to leaf water potential showed highly significant difference between varieties and among different water stress levels. Wheat cultivar Inqlab91 had significantly greater leaf water potential (-0.98 MPa) than Uqab-2000 (1.14 MPa). Water stress reduced the leaf water potential. The maximum water potential was maintained by plants grown under normal conditions (-0.63 MPa). The water potential was the minimum in $\mathrm{T}_{3}(-1.49 \mathrm{MPa})$. Osmotic potential significantly reduced with the application of water stress, which was the highest $(-1.39 \mathrm{M} \mathrm{Pa})$ in the plants growing under control conditions, while it was the minimum (- $1.56 \mathrm{MPa}$ ) in $\mathrm{T}_{3}$ (Fig. IC). Significant variations were recorded in osmotic potential of the cultivars. However, lnqlab-91 had significantly greater osmotic potential (-1.44 MPa) than Uqab-2000 (-1.51 MPa). The turgor potential was decreased with the increase of water stress in both the wheat cultivars (Fig. ID). The highest turgor potential was recorded for control (0.76 MPa), while it was the minimum in $\mathrm{T}_{3}(0.06 \mathrm{MPa})$. Both the wheat cultivars showed significant variations for turgor potential. Cultivar lnqlab-91 maintained significantly greater turgor potential (0.46 MPa) than Uqab-2000 (0.37 MPa).

Turgor potential was the maximum in plants of $T_{0}$ and $T_{1}$ treatments, while it was the minimum in plants subjected to water stress at anthesis and both at tillering and anthesis treatments. Average turgor potentials (MPa) were 0.76 and 0.06 in $T_{0}$ and $T_{3}$ treatments, respectively. Statistically $T_{2}$ and $T_{3}$ treatments were at par with each other (Fig. ID).

Interactions between cultivars and among different water stress treatments were also highly significant. All these interaction showed that turgor potential was maximum in $\mathrm{V}_{1}$ (lnqlab-91) and minimum in $\mathrm{V}_{2}$ (Uqab-2000) in $\mathrm{T}_{0}$ and $\mathrm{T}_{1}$ treatments. Turgor potential was the same in both $V_{1}$ and $V_{2}$ for $\mathrm{T}_{2}$ and $\mathrm{T}_{3}$ treatments.

\section{Growth}

In both the cultivars, LAI continued to increase from 36 DAS $(<1)$ to 92 DAS (4.3) and then gradually declined towards the final harvest (Fig. 2a). Differences in LAI development were of the cultivars significant only after the booting stage. However, the variety Inqlab-91 produced significantly more LAI than Uqab2000. Maximum LAI was recorded on 92 DAS harvest in both the cultivars which ranged from 4.08 for cv. Uqab-2000 to 4.32 for the variety Inqlab-91 (Fig. 2a). Different water stress levels affected LAI significantly. Drought imposed at different crop growth stages reduced LAI significantly as compared to that of the fully irrigated plants. Maximum LAI (5.18) was produced (92 DAS) by fully irrigated crops (Fig. 2b). Maximum LAI varied from 3.14 to 5.18 among different water stress treatments on 92 DAS (Fifth harvest). Thereafter, it 
declined to $<2.0$ on 192 DAS. Minimum LAI was produced in $T_{3}$ treatment. The drought imposed only at vegetative stage $\left(T_{1}\right)$ reduced less LAI than the drought experienced by the crops at vegetative plus the anthesis stage $\left(\mathrm{T}_{3}\right)$. The drought at anthesis $\left(\mathrm{T}_{2}\right)$ did not reduce LAI when compared to that of $\mathrm{T}_{0}$ indicating that if there is a little shortage of water only for a few days at anthesis. LAI would not be affected adversely provided that water is available.

Crop growth rate (CGR) for the varieties was slower during early vegetative phase of the crop due to lower temperature; thereafter it increased sharply. Cultivar Inqlab-91 had significantly greater mean CGR $\left(12.31 \mathrm{~g} \mathrm{~m}^{-2} \mathrm{~d}^{-1}\right)$ than that of Uqab-2000 (11.60 $\left.\mathrm{g} \mathrm{m}^{-2} \mathrm{~d}^{-1}\right)$ at final harvest. On an average, CGR for cultivars ranged from $12 \mathrm{gm}^{-2} \mathrm{~d}^{-1}$ to $39 \mathrm{gm}^{-2} \mathrm{~d}^{-1}$ (Fig. 3c). Moisture stress at different crop growth stages affected CGR differently. Fully irrigated crops $\left(\mathrm{T}_{0}\right)$ indicated significantly greater CGR than other crops throughout the season. Nevertheless, the crops which were stressed only at the anthesis stage $\left(T_{2}\right)$ have shown statistically similar results. At final harvest, the average CGR values for $\mathrm{T}_{0}, \mathrm{~T}_{2}$, and $\mathrm{T}_{3}$ were $12.58,11.48,12.28$, and $11.47 \mathrm{~g} \mathrm{~m}^{-2} \mathrm{~d}^{-1}$, respectively (Fig. $3 d)$. Interaction between the cultivars and different leves of water stress remained non-significant throughout the season.

Table 2. Effect of water stress on number of tillers, fertile tillers, spike length and number of spikelets/spike of two wheat cultivars.

\begin{tabular}{l|l|l|l|l}
\hline $\begin{array}{c}\text { Cultivars/ } \\
\text { Treatments }\end{array}$ & No. of tillers $/ \mathrm{m}^{2}$ & $\begin{array}{c}\text { No. of fertile } \\
\text { tillers } / \mathrm{m}^{2}\end{array}$ & Spike length $(\mathrm{cm})$ & $\begin{array}{c}\text { No. of } \\
\text { spikelets spike }\end{array}$ \\
\hline Cultivars & & & & \\
Inqlab-91 & $693.3 \mathrm{~b}$ & $667.1 \mathrm{a}$ & $11.94 \mathrm{a}$ & $18.00 \mathrm{a}$ \\
Uqab-2000 & $720.0 \mathrm{a}$ & $664.5 \mathrm{~b}$ & $9.90 \mathrm{~b}$ & $15.58 \mathrm{~b}$ \\
\multicolumn{1}{l}{ Water stress treatment } & & & \\
$\mathrm{T}_{0}$ & $698.8 \mathrm{a}$ & $673.0 \mathrm{~b}$ & $11.57 \mathrm{a}$ & $17.83 \mathrm{a}$ \\
$\mathrm{T}_{1}$ & $665.8 \mathrm{~b}$ & $642.3 \mathrm{~b}$ & $10.42 \mathrm{~b}$ & $16.00 \mathrm{~b}$ \\
$\mathrm{~T}_{2}$ & $703.0 \mathrm{a}$ & $670.7 \mathrm{a}$ & $11.48 \mathrm{a}$ & $17.50 \mathrm{a}$ \\
$\mathrm{T}_{3}$ & $663.0 \mathrm{~b}$ & $637.0 \mathrm{~b}$ & $10.38 \mathrm{~b}$ & $15.83 \mathrm{~b}$ \\
\hline $\mathrm{CV}(\%)$ & 2.93 & 2.68 & 4.51 & 3.74 \\
\hline
\end{tabular}

Note: In a column, means followed by common letter (s) are not significantly different at $5 \%$ level by LSD

\section{Yield and yield components}

Data concerning the number of tillers per unit area showed that number of tillers $/ \mathrm{m}^{2}$ were significantly affected by different levels of water stress (Table 2). The cv. Inqlab-91 produced higher number of tillers than that of Uqab-2000. Among the after stress treatments, $T_{0}$ gave statistically significant increase in the 
number of tillers over $T_{1}, T_{2}$, and $T_{3}$ treatments, respectively. Treatment $T_{1}$ and $\mathrm{T}_{2}$ were statistically non-significant to each other. Both the wheat cultivars produced almost same number of fertile tillers (Table 2). In case of water stress treatments, $T_{0}$ produced the maximum number of fertile tillers as compared to $T_{1}$, $T_{2}$, and $T_{3}$. The data relating to spike length as influenced by water stress applied at different growth stages is presented in Table 2. The cv. Inqlab-91 showed significant increase $20.61 \%$ in the spike length as compared to cv. Uqab-2000. Treatment $T_{0}$ gave the maximum spike length. Both the treatments $T_{1}$ and $T_{3}$ showed non-significant increase in the spike length.

Table 3. Effect of water stress on number of grains/spike, 1000-grain weight, biological yield, grain yield, harvest index and net assimilation rate (NAR) of two wheat cultivars.

\begin{tabular}{|c|c|c|c|c|c|c|}
\hline $\begin{array}{l}\text { Cultivars/ } \\
\text { Treatments }\end{array}$ & $\begin{array}{l}\text { No. of } \\
\text { grains/ } \\
\text { spike }\end{array}$ & $\begin{array}{c}\text { 100-grain } \\
\text { wt (g) }\end{array}$ & $\begin{array}{c}\text { Biological } \\
\text { yield } \\
\text { (kg/ha) }\end{array}$ & $\begin{array}{l}\text { Grain } \\
\text { yield } \\
\text { (kg/ha) }\end{array}$ & $\begin{array}{c}\text { Harvest } \\
\text { Index (\%) }\end{array}$ & NAR \\
\hline \multicolumn{7}{|l|}{ Cultivars } \\
\hline Inqlab-91 & 51.66 a & $40.78 \mathrm{a}$ & 13233 a & $3985 a$ & $30.25 a$ & 6.40 \\
\hline Uqab-2000 & $48.83 \mathrm{~b}$ & $38.18 \mathrm{~b}$ & $12460 \mathrm{~b}$ & $3314 b$ & $26.76 b$ & 6.50 \\
\hline \multicolumn{7}{|c|}{ Water stress treatment } \\
\hline $\mathrm{T}_{0}$ & $53.00 \mathrm{a}$ & $42.86 a$ & 13550a & $4215 a$ & 30.11 & $7.58 \mathrm{a}$ \\
\hline $\mathrm{T}_{1}$ & $50.83 b$ & $40.89 \mathrm{~b}$ & $12340 \mathrm{~b}$ & $3468 b$ & 27.94 & $5.38 \mathrm{~b}$ \\
\hline $\mathrm{T}_{2}$ & $48.33 c$ & $37.96 \mathrm{c}$ & 13200a & $3887 a$ & 29.08 & $7.57 \mathrm{a}$ \\
\hline $\mathrm{T}_{3}$ & $48.83 \mathrm{c}$ & $36.23 c$ & $12300 \mathrm{~b}$ & $3307 \mathrm{~b}$ & 26.90 & $2.29 b$ \\
\hline CV (\%) & 2.33 & 3.68 & 5.08 & 7.30 & 9.05 & 4.59 \\
\hline
\end{tabular}

Note: In a column, means followed by common letter (s) are not significantly different at $5 \%$ level by LSD.

Maximum number of spikelets/spike was observed in $\mathrm{T}_{0}$ which vas 11.44 and $12.63 \%$ more than $\mathrm{T}_{1}$ and $\mathrm{T}_{3}$, respectively, when water stress was imposed both at tillering and anthesis stages. The wheat cultivar lnqlab-91 gave $15.53 \%$ more number of spikelets/spike than Uqab-2000. Similarly maximum number of grains/spike was recorded in $\mathrm{T}_{0}$ which was $10 \%$ higher than those plants which were exposed to water stress at anthesis stage. The cultivar Inqlab-91 produced significantly higher number of grains/spike than that of Uqab-2000. Significant differences in 1000-grain weight were noted among various water stress treatments. $\mathrm{T}_{0}$ had significantly higher (18.29\%) 1000-grain weight than all other water stress treatments. $T_{1}$ exhibited significant higher 1000-grain weight than $T_{2}$ and $\mathrm{T}_{3}$. The cv. lnqlab-91 had higher 1000-grain weight than cv. Uqab-2000. Similarly, maximum biological yield (13550 kg/ha) was recorded for $\mathrm{T}_{0}$ which was $10 \%$ higher than that of $\mathrm{T}_{\mathrm{I}}$ and $\mathrm{T}_{3}$. The data in relation to the biological yield 
exhibited significant effect both for varieties and different water stress levels. The cv. Inqlab-91 produced more biological yield than cv. Uqab-2000. The data regarding the grain yield showed significant difference in both for varieties and water stress levels. The cv. Inqlab-91 produced the higher (20\%) grain yield than cv. Uqab-2000. Maximum grain yield was observed in $\mathrm{T}_{0}$ which were 18 and $22 \%$ more than $\mathrm{T}_{1}$ and $\mathrm{T}_{3}$ treatments, respectively, when water stress was imposed both at tillering and anthesis stages. Harvest index (HI) was significantly influenced between cultivars. Different moisture stress treatments exhibited non-significant effects on $\mathrm{HI}$ and it ranged from 26.90 to $30.11 \%$ among different water stress treatments (Table 2). Net assimilation rate (NAR) was non-significant between the cultivars.

Maximum NAR was observed in case of $\mathrm{T}_{0}$ ) that was $29.02 \%$ more than $\mathrm{T}_{1}$ and $30.21 \%$ more than $\mathrm{T}_{3}$ treatments, respectiv1y, when water stress was imposed both at tillering and anthesis stage.

\section{Discussion}

It is a fact that yield and yield components of the plant in drying soil are reduced even in tolerant genotypes. The grain yield depends on number of tillers surviving up to maturity, spike length, fertile spikelets, seed per ear and grain size (1000-grain weight). In the present study, water deficit at different growth stages reduced number of tillers initiated and surviving up to maturity, and the number of spikelets or seeds per ear. Both Sharif (1999) and Musaddique et al. (2000) reported that greater than 400 tillers $/ \mathrm{m}^{2}$ were obtained in wheat in control treatment in which maximum number of irrigation was applied. McDonald (1984) found that maximum number of tillers were associated with greater number of irrigations. The importance of fertile tillers is evident from the fact that it affects directly the final grain yield. Matsunaka et al. (1992) and Ghazal et al. (1998) also reported that number of spikes $/ \mathrm{m}^{2}$ increased as irrigation increased. Many researchers have reported similar effect of irrigation on spike length in wheat (Swati et al., 1985; Ahmad, 1994). Dencic (2000) and Shehzadi (1999) concluded that spikelets/spike are more sensitive to drought stress in different cultivars of wheat. Many workers reported a range of grain number varying from 40 to 59 grains/spike among various genotypes of wheat (Hussain et al., 1997; Maddique et a1., 2000). Similar effects of water stress on 1000-grain weight were atso reported (Qadir et al., 1999; Shehzadi, 1999 and Dencic et al., 2000). These findings are supported by Kang et al. (2002) and Pirdasti et al. (2004) who reported a positive correlation between spiktets per ear and 1000grain weight and grain yield. Ashraf (1998) reported that the productive spikes per plant contribute in increasing the yield under water deficit conditions. In the present study, the fertile spikelets per ear and 1000-grain weight were influenced by the water stress applied at different stages. The sensitivity of grain yield to 
drought was found to be depended upon the severity of stress and the stage when it was applied. The combined stress at tiltering and anthesis stages caused more reduction in grain yietd as compared to that at tillering or anthesis stage alone. It woutd be reasonable to conclude that grain yield is severely reduced if irrigation is not applied at tillering and anthesis stages. However, if crop faces drought only at tillering or anthesis stage, economical yield can be obtained from the crop. The results of Kang et al. (2002) and Pirdashti et al. (2004) agree with the results obtained in this study. Giunta et al. (1993). Pannu et al. (1996) also obtained the same results.

Various forces act through soil-plant-atmosphere continuum which allow the uptake and loss of water and constitute the water relations. The plant component consists of relative vater contents (RWC), water potential $\left(\psi_{\mathrm{w}}\right)$, osmotic potential $\left(\psi_{\mathrm{s}}\right)$ and turgor potential $\left(\psi_{\mathrm{p}}\right)$. The study of water retations is important for several reasons. Firstly the differences in water relation characteristics reflect the differences between species and cultivars and are considered as an indicator of drought resistance or adaptation to drought (Ashraf et al. 1994). It is documented that reduction in RWC has affected the growth and yield of the ptants (Hafid et al., 1998, DePereira-Neto et al., 1999, Molnar et al., 2002) and present study confirmed the above statement. Ashraf and Khan (1993) and Ashraf et al. (1994) evaluated the excised leaf water retention capabilities of wheat cultivars and found that genotypes with higher RWC were more drought tolerant. In the present study, the RWC reduction in both the genotypes was recorded under water stress conditions. However, Inqlab-92 maintained higher RWC than Uqab90 (Fig. IA). The highest reduction in RWC was at $T_{3}$ followed by $T_{2}$ and $T_{1}$. Ashraf et al. (1994), Hafid et al. (1998), DePereira-Neto et al. (1999), Molnar et al. (2002) and Siddique et al. (2000) reported that leaf survival necessary for assimilation is determined by RWC rather than by leaf water potential. The finding of present study supports the possibility that RWC could be used as indicator of drought resistance.

Water stress decreases the leaf water potential of the plants (Siram et al. 1990; Ashraf et al., 1994) and it is considered a reliable parameter for quantifying plant water stress response and screening drought tolerant genotypes. Variations in leaf water potential between both the wheat cultivars under moisture stress were recorded. Higher leaf water potential was found in lnqlab91 than Uqab-2000. Siram et al. (1990) reported that decrease in leaf water potential increased the intensity of drought stress. In present study, reduction in leaf water potential was observed maximum in $T_{3}$ where stress was applied on two stages (stem elongation and anthesis). Ashraf et al. (1 994) reported the similar findings.

Ashraf et al. (1994) reported that osmotic adjustment results from the accumulation of solutes which lowers the osmotic potential and helps in 
maintaining turgor of plants experiencing water stress. It is reported that faster decrease in osmotic potential is essential to maintain the potential differences to allow water uptake by the root. The present study confirmed that with the fall in leaf water potential due to soil water deficit simultaneous fall in osmotic potential was observed (Fig. IB). The fall in leaf osmotic potential was found with water stress in both the wheat cultivars. Ashraf and Khan (1993) and Ashraf et al. (1994) confirmed the above findings. In the present study, negative relationship between yield and osmotic potential was found. Ashraf et al. (1994) also did not find any relationship between yield and osmotic potential.

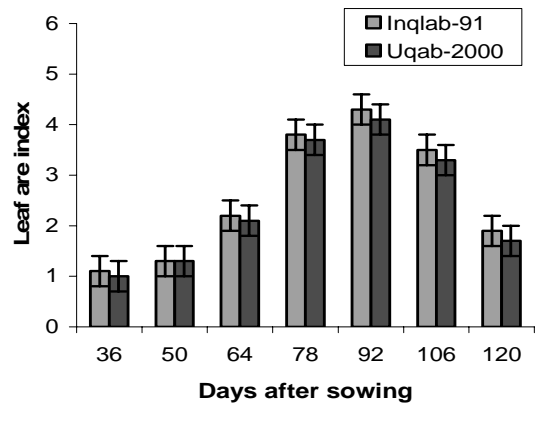

(a)

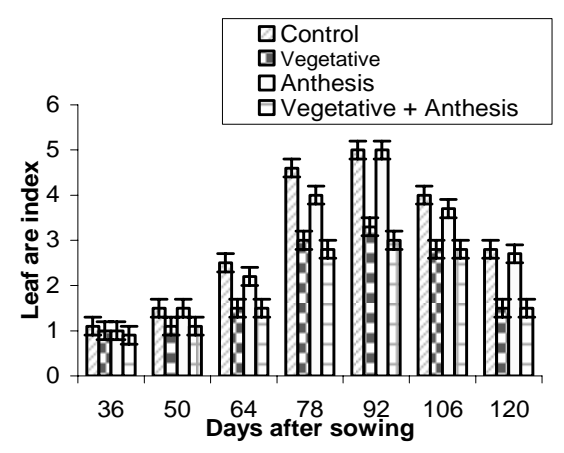

(B)

Fig. Leaf area index as affected by water stress treatments \pm S.E.

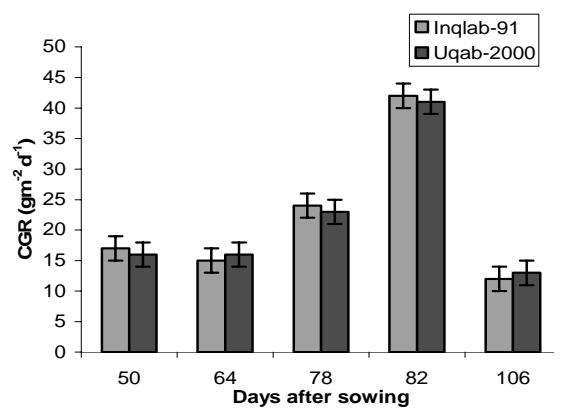

(c)

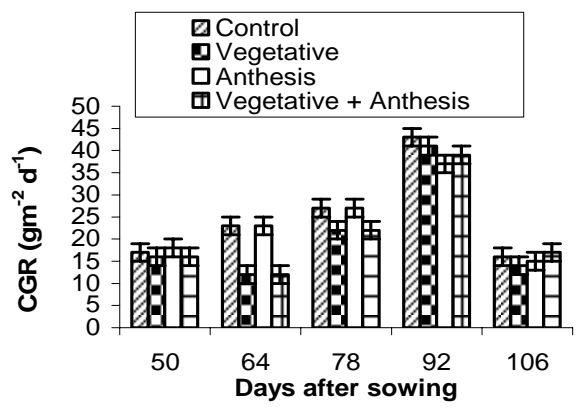

(d)

Fig. 3. Crop growth rate (CGR) as affected by different water stress treatments \pm S.E.

Literature (Ashraf et al., 1994 and 2002) showed that many important physiological and morphological proesses, such as leaf enlargement, stomatal conductance and photosynthetic activity are directly affected by leaf turgor potential. Under water stress conditions, plants lose their turgor and thus cell 
expansion and growth are reduced (Siddique et al., 2000). So the plants must adjust turgor to resume cell expansion and growth. But according to Munns (1979), the major mechanism of major maintenance is osmoregulatory. During osmoreguation, solutes accumulate. As a result, decreasing in the osmotic potential, consequenoy, uptook water for maintaining turgor. In the present study, lowering in osmotic potential was observed with the application of water stress (Fig. IC). Ashraf et al. (1994) found that genotype, which maintained higher turgor, was tolerant to drought. The same finding was obtained for present study. Inqlab-91 maintained higher turgor which enchaned higher photosynthetic activity leading to higher grain yield than Uqab-2000.

Growth analysis provides fundamental basis for characterization of a plant response to environmental stresses. Leaf area index is the main physiological determinant of crop yield. Possible cause of reduction in leaf area index might be due to reduction in cell enlargement (Mccrec and Davis, 1974), stunted growth (Jones et al., 1980) and reduced photosynthetic activity of leaves (Oppenheimer, 1960). Increased abscission rate due to the decrease in water status of the plant under stress may be another reason of the reduction in LAI. Interaction between the cultivars and different water stress levels was non-significant. The results of the present investigation are in line with Qadir et al. (1999) who concluded that water stress during vegetative growth caused reduction in LAI of wheat. Mosaad et al. (1995) also showed similar responses of wheat crop under water stress conditions. Crop growth rate expresses the rate of dry matter accumulation that provides useful information regarding the nature and intensity of stress effect on plant growth. In the present study, water stress markedly reduced crop growth and reduced shoot biomass decline in growth observed in many plants subjected to water stress is often associated with a decrease in their photosynthetic capacity.

\section{Conclusions}

From the results, it can be concluded that water stress significantly altered the internal water status by decreasing RWC, water potential, and osmotic potential of wheat that consequently decreased the turgor potential. The cultivar Inqlab-91 proved to be the most water economic when subjected to water stress, evidenced by reservation of more water contents in the plant tissue and high yield levels. All these characters account for its highest productivity under shortage of water supply. Overall, it is advised to grow this cultivar of wheat in land areas with limited supply of irrigation water. 


\section{Acknowledgement}

The authors are thankful to the Department of Crop Physiology, University of Agriculture, Faisalabad for providing financial support to conduct this experiment. The authors are also very thankful to Dr. S.M. Shahzad for reviewing this manuscript.

\section{References}

Ahmad, J. 1994. Effect of varying irrigation frequencies on phenology, growth and yield of three wheat varieties. M.Sc Thesis. Dept. Agron. Univ. Agric., Faisalahad.

Araus, J. L., G Slafer, M. P. Reynolds and C. Royo. 2002. Plant breeding and drought in $\mathrm{C}_{3}$ cereals. What should we bread for? Ann. Bot. 89: 925-940.

Ashraf. M.Y. 1998. Yield and yield components response of wheat (Triticum aestivum L.) genotypes tinder different soil waler deficit conditions. Acta Agron. Hung. 46: 45-5 1

Ashraf. M.Y. I 998b. Photosynthetic efficiency of wheat under water stress conditions. Pak. J. Scientific and Industrial Res. 41: 15 1-163.

Ashraf, M. Y., K. Akhtar, G. Sarwar and M. Ashraf. 2002. Evaluation of arid and Semiarid ecotypes of guar (Cyamopsis tetragonobola L.) for salinity (NaCI) tolerance. $J$. Arid. Environ. 15: 437- 482.

Ashraf, M. Y., A. R. Azmi, A. H. Khan and S. S. M. Naqvi. 1994. Water relation in different wheat (Triticum aestivum L.) genotypes under water deficit. Acta Physiol. Plant. 3: $231-240$.

Ashraf, M. Y. and A. R. Khan. 1993. Effect of drought stress on wheat plant in early stages. Pak. J. Agri. Res. 4: 261-269.

Bukhat, N. M. 2005. Studies in yield and yield associated traits of wheat (Triticum aestivum L.) genotypes under drought conditions. M.Sc Thesis Department of Agronomy. Sindh Agriculture University, Tandojam, Pakistan.

De Pereira-Netto, A. B., A. C. N.De Maganhaes and H. S. Pinto. 1999. Effect of soil water depletion on the water relation in tropical Kudzu. Pesq. Agropec. Bras, Brasila. 7: 1151-1157.

Dencic, S., R. Kastori, B. Kobiljski and B. Duggan. 2000. Evaporation of' grain yield and its components in wheat cultivars and land races under near optimal and drought conditions. Euphytica 1: 43-52 (Wheat. Barley and Triticale Absis. 3: 1197).

Ghazal, H. M., M. Z. Wassouf, M. M. Nachit and A. A. .Iaradat. 1998. Yield and yield components of' durum wheat as influenced by irrigation and nitrogen fertilization. Proc. $3^{\text {rd }}$ Int. Triticeae Synip, Aleppo., Syria, 4-8 May: 445-449 (CAB. Absts., 1998).

Giunata, F., R. Motzo and M. Deidd. 1993. Effect of drought on yield and yield components of durum Wheat and triticale in a Mediterranean environment. Field Crop Res. 33: 399-409. 
Gupta. N. K., S. Gupta and A. Kumar. 2001. Effect of water stress on physiological attributes and their relationship with growth and yield in wheat cullivars at different growth stages. J. Agron. 86: 143 7-1439.

Hafid. R. E., D. H. Smith, M. Karrou and K. Samir. 1998. Physical responses of spring durum in a Mediterranean environment. Ann. Bot. 81: 363-370.

Hunt. R. 1978. Plant growth analysis. pp. 26-38. Edward Arnold, Olondon, UK.

Hussain, T. 1997. Comparative growth and yield performance of various wheat cultivars. M.Sc Agri. Thesis, Univ. Agric., Faisalabad.

Jamal, M., M. S. Nazir, S. H. Shah and A. Nazir. 1996. Varietals rcsponse of wheat to water stress at different growth stages and effect on grain yield, Straw yield, harvest index and protein content in grains. Rachis 2: 38-45.

Jones, M. B., E. L. Leafe and W. Stile. 1980. Water stress in field grown perennial rye grass, Its effect on growth, canopy photosynthesis and transpiration. Ann. Appl. Biol. 2: $87-101$.

Kang, S, L. Zhang., Y. Lian and H. Cai. 2002. Effect of limited irrigation on yield and water use efficiency of winter wheat on the loess plateau of China. Regional water and soil Assessment for managing sustainable agriculture in China and Australia. ACIAR Monograph No. 84: 105-116.

Karrou, M., and J. W. Maranville. 1995. Response of wheat cultivars to different soil nitrogen and moisture regimes: II. Leaf water content, stomatal conductance and photosynthesis. J. Plant Nuitr. 4: 777-791.

Mark, T. and B. Antony. 2005. Abiotic stress tolerance in grasses from model plants to crop plants. Plant Physiol. 137: 79 1-793.

Matsunaka, T., H. Takeuchi and T. Miyawaki. 1992. Optimum imgation period for grain production in spring wheat. Soil Sci. Op. and PL. Nutr. 2: 269-279 (Field Crop Absts., 1994, 8: 4740).

Mc Donald. G. K.. B. G. Sutton and F. W. Ellison. 1984. The effect of sowing dates, irrigation on growth and yield of wheat in Namoi. River Vally. New South Wales, Irrigation Science. 2: 123-135 (Wheat, Barley and Triticale Absts., 1984, 4: 3401).

Mccree, K. .J. and S. D. Davis. 1974. Effect of water stress and temperature on leaf epidermal cells in grain sorghum. Crop Sci. 5: 75 1-755.

Molnar, I., L. Gaspar, L. Stehli, S. Dulai, E. Sarvari, 1. kirali, G. Galiba and M. MolnarLang. 2002. The effect of drought stress on the photosynthetic processes of wheat and of Aegilops biuncialis genotype originating from various habitats. Acta. Biol. Szeged. 4: 115-116.

Mosaad. M. G., G. Ortiz-Ferranru and V. Mahalakshmi. 1995. Tiller development and contribution to yield under different moisture regimes in two triticum species. $J$. Agron. and Crop Sci.. pp. 173- 180 (Field Crop Absts., 48(10): 71 66; 1995).

Munns, R., J. Brady and E. W. Barlow. 1979. Solute accumulation in the apex and leaves of wheat (Triticum aestivum L.) water stress. Aust. J. Plant Physiol. 3: 379-390. (Biol. Absts.. 1980, 3: 19473). 
Musaddique, M., A. Hussain. A. Wajid and A. Ahmad. 2000. Growth, yield and components of yield of different genotypes of wheat. Int. J. Agric. Biol. 2: 242-244.

Oppenheimer, H. R. 1960. Adaptation to drought, xerophytisim. In "Plant water relationships in Arid and Semi-arid conditions. Proc. Marid syp. UNESCO. Paris, pp. 105-138.

Pannu, R. K.. P. Singh, D. P. Singh. B. D. Chaudhry, V. P. Sangwan and H. C. Sharma. 1996. (ground water table limits the irrigation requirement of tall and dwarf wheat (Triticum aestivum L.). Indian J. Agron. 41: 568-572.

Pirdashti, H., Z. T. Sarvestani, G. Nematzadch and A. Ismail. 2004. Study of water stress effects in different growth stages on yield and yield components of different rice (Oryza sativa L.) cultivars. $4^{\text {th }}$ Int. Crop Sci. Congress. P. 1-7.

Qadir, G., Saeed, M. and M. A. Cheema. 1 999. Effect of water stress on growth and yield perforrmance of four wheat cultivars. Pak. J. Biological Sci. 1: 236-239.

Siram, R. K., S. P. Deshrnukh, S. D. Shukia and S. Ram. 1990. Metabolic activity and grain yield under moisture stress in wheat genotypes. Ind. J. Plant. Physiol. 3: 226231. (Crop Physiology Absts; 17(11): 4415; 1991).

Salter, P. J. and J. E. Goude. 1967. Crop responses to water at different stages of growth. Research Review No. 2. Common Wealth Bureau of Horticultural and Plantation Corps. p. 246.

Sarwer, A. 1994. Response of wheat to soil moisture stress at different stages of growth. J. Drainage and Reclamation. 4: 41-47.

Sharif. M. 1999. Effect of irrigation at different growth stages on growth and yield performance of wheat cultivars. M.Sc. Agri., Thesis, Univ. Agric.. Faisalahad.

Shehzadi, S. 1999. Effect of different water regimes on growth, yield and anatomy of wheat (Triticum aestivum L.). M.Sc Thesis, Deptt. Bot., Univ. Agric., Faisalabacl.

Siddique, B. M. R., A. Hamid and M. S. Islam. 2000. Drought stress effect on water relation of wheat. Bot. Bull. Acad. 41: 35-39.

Steel, R. G. D., J. H. Torrie and D. A. Deekey. 1997. Principles and procedures of statistics: A Biometrical Approach. 3rd ed. McGraw Hill Book Co. Inc. New York. pp. 400-428.

Swati, M. S., H. Rahman and J. Afsar. 1985. Response of wheat (Triticum aestivum L.) cultivars to different levels of water stress. Sarhad J. Agric. 2: 295-303.

Zhang, H. P. and T. Oweis. 1998. Water yield relation and optimal irrigation scheduling of wheat in Mediterranean regions. Agriculture water management. vol, 3, pp. 195211 (Wheat Barley and triticale absts. 2: 916). 